\title{
CDISC SDTM Laboratory Test Code Terminology
}

National Cancer Institute

\section{Source}

National Cancer Institute. CDISC SDTM Laboratory Test Code Terminology. NCI

Thesaurus. Code C65047.

A terminology set that includes concepts contained in the CDISC laboratory test codelist. 